\title{
Obesity and the Kidney: Heavy Burden of the Epidemic
}

\author{
Asserraji Mohammed* \\ Nephrology Consultant, Armed Forces Hospital Militaire Avicenne, Morocco
}

Submission: February 24, 2018; Published: March 14, 2018

*Corresponding author: Asserraji Mohammed, Nephrology Consultant, Nephrology Unit, Armed Forces Hospital Militaire Avicenne, Marrakesh, Morocco, Email: asserrajimed@hotmail.com

\begin{abstract}
The 2017 world kidney day (WKD) theme was "Kidney Disease \& Obesity" [1]. The choice of this topic underlines the increasing burden of both obesity and chronic kidney diseases (CKD) prevalence worldwide. In nephrology, the growing incidence of obesity, expose patients to special CKD known as obesity related glomerulopathy (ORG), a distinct entity including proteinuria, glomerular hypertrophy, progressive glomerulosclerosis and CKD. In this paper, we discuss the renal pathophysiology effects of obesity, the pathologic finding and the clinical features of ORG with some key points regarding the management of renal effect of obesity.
\end{abstract}

\section{Introduction}

The 2017 world kidney day theme was "Kidney Disease \& Obesity" [1]. The choice of this topic underlines the increasing burden of both obesity and chronic kidney diseases (CKD) prevalence worldwide $[1,2]$. Over the past three decades, the prevalence of obesity (BMI $\geq 30 \mathrm{~kg} / \mathrm{m} 2$ ) among adults aged 20 74 years has more than doubled, in the USA [2]. This increase occurred in men and women of all age groups and across diverse ethnicities [2-4]. By 2030, estimates predict that more than $50 \%$ of the US population will be obese [2-5]. In nephrology, the growing incidence of obesity, expose patients to special CKD known as obesity related glomerulopathy (ORG), a distinct entity including proteinuria, glomerular hypertrophy, progressive glomerulosclerosis and CKD [1-5].

\section{Mechanisms of renal effects of obesity}

The exact effect by which obesity may causes or worsens CKD is unclear. In the setting of obesity, the main kidney physiologic responses are increases in glomerular filtration rate and tubular reabsorption of sodium. Renin-angiotensin-aldosterone system (RAAS) and the renal sympathetic nervous system (RSNS) are also stimulated in this condition. All these physiologic reactions could lead to development of ORG. In addition, inflammatory adipokines produced by adipocytes might promote maladaptive cellular responses to glomerular hyperfiltration and albuminuria.

\section{The pathologic concept of obesity-related glomeru- lopathy (ORG)}

The first case reports of ORG were described in autopsy studies as a strange association between extreme obesity and the development of glomerular hypertrophy [1,2]. Renal biopsies are currently performed in obese patients. ORG is a distinct and authentic renal involvement of obesity. Based on detailed clinical-pathologic studies, the pathologic features of ORG include glomerulomegaly and a particular focal segmental glomerulosclerosis (FSGS) well known as perihilar variant of FSGS [2-6]. Several reports showed an important increase the ORG incidence from $0.2 \%$ to $2.0 \%$ in ten years (1990-2000).It is well admitted that ORG could be seen in all obesity grades [4-6].

\section{Clinical features of ORG}

The mainclinical presentation of ORG includes isolated proteinuria with or without renal insufficiency. These renal manifestations are usually associated with hypertension (50$75 \%)$ and dyslipidaemia (70-80\%) [1,2]. Proteinuria, assessed by semiquantative dipstick (grade $1+$ or more) or macroalbuminuria measurement (albumin: creatinine ratio $>300 \mathrm{mg} / \mathrm{g}$ ) is present in $4-10 \%$ of obese patients, especially in some Asian countries [1-7]. Nephrotic-range proteinuria (3 grams or more per day) is unusual. Full nephrotic syndrome is very rare in obese patients. 
The clinical ORG evolution is characterized by slowly progressive proteinuria [2-8]. However, 10 to $33 \%$ of patients may develop progressive renal failure and end stage renal disease (ESRD) [610].

\section{Management of renal effect of obesity}

The treatment target in ORG is reduction of proteinuria and blood pressure [2]. RAAS blockade including angiotensine conversion enzyme (ACE) inhibitors or angiotensin-receptor blockers (ARBs) are well indicated. Weight reduction could reduce proteinuria as well [1,2].

\section{References}

1. Câmara NO, Iseki K, Kramer H, Liu ZH, Sharma K (2017) Kidney disease and obesity: epidemiology, mechanisms and treatment. Nat Rev Nephrol 13(3): 181-190.

2. D’Agati VD, Chagnac A, de Vries AP, Levi M, Porrini E, et al. (2016) Obesity-related glomerulopathy: clinical and pathologic characteristics and pathogenesis. Nat Rev Nephrol 12(8): 453-471.

3. Kambham N, Markowitz GS, Valeri AM, Lin J, D’Agati VD (2001) Obesityrelate glomerulopathy: anemerging epidemic. Kidney Int 59(4): 14981509.
4. Chen HM, Li SJ, Chen HP, Wang QW, Li LS, et al. (2008) Obesity-related glomerulopathy in China: a case series of 90 patients. Am J Kidney Dis 52(1): 58-65.

5. Kovesdy CP, Furth SL, Zoccali C, World Kidney Day Steering Committee (2017) Obesity and kidney disease: Hidden consequences of the epidemic. J Nephrol 30(1): 1-10.

6. Coresh J, Selvin E, Stevens LA, Manzi J, Kusek, et al. (2007) Prevalence of chronic kidney diseasein the United States. JAMA 298 (17): 20382047.

7. Farag YM, Gaballa MR (2011) Diabesity: an overview of a rising epidemic. Nephrol Dial Transplant 26(1): 28-35.

8. Stenvinkel P, Zoccali C, Ikizler TA (2013) Obesity in CKD -what should nephrologists know? J Am Soc Nephrol 24: 1727-1736.

9. Wickman C, Kramer H (2013) Obesity and kidney disease: potential mechanisms. Semin Nephrol 33(1): 14-22.

10. Bonnet F, Deprele C, Sassolas A, Moulin P, Alamartine E, et al. (2001) Excessive body weight as a new independent risk factor for clinical and pathological progression in primary IgA nephritis. Am J Kidney Dis 37(4): 720-727.

\section{Your next submission with Juniper Publishers} will reach you the below assets

- Quality Editorial service

- Swift Peer Review

- Reprints availability

- E-prints Service

- Manuscript Podcast for convenient understanding

- Global attainment for your research

- Manuscript accessibility in different formats

( Pdf, E-pub, Full Text, Audio)

- Unceasing customer service

Track the below URL for one-step submission https://juniperpublishers.com/online-submission.php 